\title{
PRISPEVEK GEOGRAFOV INŠTTTUTA ZA RAZISKOVANJE KRASA K REŠEVANJU PROSTORSKE PROBLEMATIKE
}

\author{
Andrej Kranjc*
}

IZVLEČEK

UDK 061.6:911:551.44"1947-1987"(047)

V 40 letih delovanja Inštituta za raziskovanje krasa ZRC SAZU je pri raziskavah sodelovalo 9 geografov. Med njihovimi 800 objavljenimi deli jih 205 obravnava prostorsko problematiko krasa. Od skupno 330 elaboratov jih je 80 aplikativne narave in pri večini so soavtorji tudi geografi.

\section{ABSTRACT}

UDC 061.6:911:551.44"1947-1987"(047) THE CONTRIBUTION OF THE GEOGRAPHERS FROM THE INSTITUTE FOR KARST RESEARCH TO THE SOLUTION OF SPACE PROBLEMATICS

The Institute of karst research ZRC SAZU exists more than 40 years and during this period 9 geographers were among its staff. 205 published works treat regional problematics. Out of 330 elaborates 80 have applied orientation, the geographers as coauthors mostly.

\section{ZGODOVINA IZRK}

Zamisel, da bi Postojna postala svetovni ali vsaj evropski krasoslovni in speleoloski center $\mathrm{z}$ združitvijo gospodarske (turizem), kulturno-pedagoške (kraški muzej) in znanstvene (krasoslovni inßtitut) dejavnosti, je že stara, saj izvira z zaCetkov tega stolet ja. Jamska komisija si je v novi okrožni zgradbi uspeia zagotoviti (1908) prostore za jamski muzej. Takorekox v celoti pa je uspel to zamisel uresničiti I.A. Perko kot jamski tajnik oziroma direktor (1909-1940): Postojnska jama je postala državna imovina, ki je finansirala Italijanski speleoloski institut (ustanovljen 1929), ta pa je imel tudi kraski muzej - le za muzej niso uspeli dobiti svoje zgradbe in je bil $\mathrm{v}$ isti stavbi, kot inštitut.

Slovenska akademija znanosti in umetnosti je 1947 ustanovila svoj Zavod za raziskavo krasa (Speleološki inštitut), ki je bil 1954 preimenovan v Institut za raziskovanje krasa in je sedaj (od 1984) v sklopu Znanstvenoraziskovalnega centra SAZU. Razlogi, da so inštitut locirali v Postojni, so bili, poleg (neomenjane) tradicije, Biospeleološka postaja v Postojnski jami, jamski muzej in tehniðna sredstva Postojnske jame (na razpolaganje Inštitutu). Teh razlogov danes ni več, inštitut pa je కe vedno v Postojni, kar ima tako dobre kot slabe strani.

\footnotetext{
* Dr. geogr., znanstv.sodel., ZRC SAZU, Inštitut za raziskovanje krasa, 66230 Postojna, Titov $\operatorname{trg} 2$, YU.
} 


\section{RAZISKOVALNA USMERITEV IZRK}

$\mathrm{V}$ prvem Statutu instituta je kot glavna naloga raziskovalnega dela navedeno: sestaviti oziroma urediti jamski kataster in odpreti speleoloß̌ke zbirke javnosti oziroma pripraviti kraški muzej. Kot programska usmeritev je veliko bliže "speleološkemu" kot pa "krasoslovnemu" inštitutu, Se najbliže pa "kraškemu muzeju".

V prvih letih obstoja je bil Se tak program preobsežen, saj v zađetku inštitut ni imel, razen upravnika (geografa A. Šerka) niti enega sodelavca. Zaradi nesreðne Šerkove smrti (1948) je inštitut $\mathrm{v}$ resnici priðel z delom šele 1950 , ko je postal v.d. upravnika $R$. Savnik in dobil rednega ter zunanje sodelavce. V 50-tih letih je ostal program bolj ali manj nespremenjen, $z$ nastopom novih raziskovalcev (geografa Gams in Habic) v za飞etku 60 -tih let, pa se je tudi pogled na raziskovalno dejavnost razširil.

Težišce raziskav se je s speleoloških preusmerjalo na krasoslovne, seveda so vse vkljuðevale in upoštevale tudi raziskave $\mathrm{v}$ kraških jamah. Pođasi so se uveljavile tri osnovne raziskovalne smeri: geoloske (s poudarkom na jamskih sedimentih), geografske (skoraj izkljuðno fiziðnogeografske) in biospeleoloske raziskave. Ker speleobiologov ni uspelo vkljuCiti $v$ inštitutsko delo (nekaj let so bili med raziskovalnim kadrom kar trije spcleobiologi), je bila ta de javnost prenešena drugam. Približno $70 \%$ raziskovalnih zmogljivosti posveca Inštitut osnovnim (fundamentalnim) raziskavam $\mathrm{s}$ skupnim naslovom Temeljno raziskovanje krasa. Te so v sklopu usmerjenega raziskovalnega programa Naravna in kuiturna dedišina slovenskega naroda (Geografsko raziskovanje krasa) in v sklopu geologije (speleogeoloske raziskave). Ostalih $30 \%$ zmogljivosti zapolnjujejo aplikativne raziskave, ki so cesto usmerjene v reševanje prostorske problematike.

\section{KADROVSKA ZASEDBA TER DELEŽ IN VLOGA GEOGRAFOV}

Dr. Alfreda Šerka, zdravnika in geografa, prvega inštitutskega upravnika, sem že omenil. V prvih desetietjih je bilo pravilo, da je upravnik akademik - tako je bil upravnik Inštituta tudi geograf akad. dr. S. Ilešx, ceprav ni bil raziskovalec v okviru Instituta in ni sodeloval pri njegovem raziskovalnem delu. Kasneje se je to pravilo spremenilo in nazadnje je bil vrsto let upravnik geograf P. Habix. Dokler ni bilo upravnika v Postojni, je bil v.d. upravnika geograf R. Savnik oziroma pomočnik upravnika P. Habic. 
Medtem ko je funkcija upravnika in njegovega pomočnika bolj upravno-administrativna, se z zasnovo raziskovalnega programa ukvarja Znanstveni svet, v katerem je vedno tudi kak geograf.

Vsega skupaj je v dobrih 40 letih na institutu delalo 9 geografov: A. Šerko, R. Savnik, I. Gams, P. Habix, F. Habe, A. Kranjc, J. Rebec, A. Mihevc, T. Slabe. Preko 10 let je bil zunanji sodelavec tudi V. Bohinec. Trenutno (1989) je na Inštitutu 13 redno zaposlenih raziskovalcev, med njimi 4 geografi, od tega 3 raziskovalci in 1 novi raziskovalec. Od ostalih 9 raziskovalcev je 5 geologov, 1 kemik, 2 arheologa in 1 zgodovinar.

\section{PROSTORSKA PROBLEMATIKA KRASA}

Rešcvanje prostorske problematike lahko gledamo ožje ali sirše. $Z$ ožjega vidika so take raziskave $v$ glavnem aplikativna dela oziroma že deli projektov. Ker so bistvo naše inštitucije fundamentalne raziskave je jasno, da je delež inštitutskih aplikativnih raziskav majhen. Vendar so tudi osnovne raziskave lahko bistvena pomod pri reševanju prostorske problematike.

Vse inštitutske raziskave so vezane na kras, Ce ne na kras kot pojav, pa regionalno na kras. Nasteti geografi so kot clani Inštituta objavili okoli 800 del. Med tcmi je 205 takih, za katere je mogoxe reci, da obravnavajo prostorsko problematiko oziroma da so neposredno vezani nanjo.

Bistveno za reSevanje prostorske probiematike je poznavanje prostora. To velja tako za normalni kot za kraški relief, morda za kraß̌kega §e bolj. K poznavanju slovenskega krasa pa so geografi - sodelavci Insttituta - bistveno pripomogli. Od 205 objav, ki jih podrobneje obravnavam, jih je 186 takih, ki podajajo rezultate regionalnih raziskav. Te so lahko prostorsko zelo omejene (Šerkova "Kotlina Škocjan pri Rakeku" 1949), ali pa res rcgionalnc (Habiðeva "Razporeditev kraških giobeli v Dinarskem krasu" 1978). Približno eno cetrtino teh del lahko oznacimo kot prave regionalne študije, saj obravnavajo doloxeno ozemlje bolj ali manj kompleksno, vsaj njihove kraške znacilnosti.

Ostala dela, ki so pripomogla $\mathrm{k}$ poznavanju slovenskega kraskega prostora, lahko podrobneje razdelimo med dela, ki govore o geomorfologiji, hidrografiji, speleologiji, klimi, o kraških procesih in o problematiki zbiranja ter urejanja prostorskih podatkov. 
Najve $\check{~ j e ~ d e l, ~ k i ~ o b r a v n a v a j o ~ h i d r o g r a f s k a ~ v p r a ł a n j a, ~ o d ~ t a k i h, ~ k i ~ d a j e j o ~ p r e g l e d ~}$ preko celote (Gamsov "Aperçu sur I' hydrologie du karst slovène et sur ses communications souterraines" 1965), do zelo ozkih v prostorskem in vsebinskem smislu (Habið \& Kogovకek "Vertikalno prenikanje vode $\mathrm{v}$ krasu na primerih Planinske in Postojnske jame" 1979 in Savnikovi "Izviri Vipave" 1959). Sledijo prispevki s speleolo§ko vsebino, pri とemer moram pripomniti, da upoštevam le tiste, ki prihajajo v poštev za šrše poznavanje prostora in so vsi prispevki zgolj z opisi jam izpušceni. Tipißna primera sta Habetov (1970) "Pred jamski podzemeljski svet" in Habix \& Gospodarix \& Kenda \& Kranjc (1975) "Osnovna speleološka karta Slovenije". Noben izmed obravnavanih 97 prispevkov hidrografske in speleoloske vsebine ne rešuje neposredno prostorskih vprašanj v smislu prostorskega nađ̌rtovanja, pađ pa je v njih toliko podatkov, ki bi k temu lahko pripomogli, da bi bila marsikatera konkretna resitev lahko ustreznejša, ce bi se jih upoštevalo oziroma poznalo. Poudarjam, da gre pri tem za objavljena (tiskana) dela, ne za claborate, ekspertize ali druge naloge. Ce spomnim na zadnja pisanja v casopisih o koðevski "ekološki bombi" - vprašanja o vodnih zvezah, onesnaženosti, potrebnih raziskavah, bi bila lahko popolnoma drugazna že samo zato, te bi bili rezultati dela geografov našega Inštituta (da ostanem le pri obravnavani temi) malo bolj znani. Tako pa se kot aktualna vpraకanja pogrevajo problemi, ki so že nekaj desetletij rešeni - le prebrati (in razumeti) bi bilo treba objave. Tako lahko povem, da so v letih 1947-1987 sodelavci Inštituta objavili 16 prispevkov samo o krasu na Koðevskem.

Skoraj enako కtevilo, kot je speleoloskih prispevkov, je tudi prispevikov, ki jih lahko uvistimo med geomorfološkc. Tudi tod gre za sirok razpon, od prispevkov, ki obravnavajo cele pokrajine (Gamsov "Morfografski pregled Novomeških pokrajin" 1962) do posameznih podrobnosti (Habetov "Morfološki, hidrografski in speleološki razvoj v studenskem flišrem zatoku" 1976). Klimi sta posebej posveðena 2 prispevka, kraskim procesom 4 (rezultate je mogoce aplicirati za uporabo pri reševanju prostorskih vprašanj). Šest prispevkov se ukvarja z vprašanjem tehnike zbiranja, hranjenja in urejanja prostorskih podatkov - $v$ glavnem gre za podatke o kraskih jamah - kar je lahko bistvenega pomena tudi pri reక̌evanju prostorskih vprašanj, se posebej, ker gre $v$ glavnem za pojave, ki so $v$ prostoru natanðno doloceni. Za primer navajam Habetov (1967) "Problem inventarizacije kraskih pojavov na Slovenskem" in Kranjc \& Jakopin (1984) "Jamski kataster v racunalniški obliki".

Varstvo narave je, postaja in mora postati vedno pomebnejłi del pri obravnavanju in reševanju prostorskih vprašanj. Večino prispevkov, ki sem jih omenil zgoraj, je mogoðe uporabiti tudi $\mathrm{v}$ zvezi $\mathrm{z}$ vprasanji varstva narave. Zato navajam posebej le prispevke, ki ncposredno govore o tem vprašanju z vidika prostora. Teh je relativno malo, najmanj, a tudi ti so razlixni, od precej splošnih pozivov (Habe "Zašciti podzemeljskega sveta bije plat zvona" 1973) do zelo konkretnih s prostorskega stališ̌a (Kranjc "Poskus valorizacije kraskih votlin v obxini Koxevje $\mathrm{z}$ naravovarstvenega vidika" 1976). 
Turizem je $\mathrm{v}$ jamah in na krasu lahko tudi del prostorske problematike, predvsem $\mathrm{v}$ regionalnem smislu. Institutski geografi so o tej temi objavili 12 prispevkov. Deloma gre bolj za nacelne oziroma teoretixne prispevke (Gams "Kraski turizem v polpretekli dobi in sedanja problematika" 1963), deloma pa za konkretne primere (Kranjc "Postojnska jama - an example of man's impact on the karst underground by tourism" 1987).

Za konec tega pregleda naj povem, da so geografi $\mathbf{v}$ okviru institutskih raziskav objavili tudi nekaj del, ki so teoretixni prispevek $\mathrm{h}$ geografiji in njenim posameznim panogam in kot take tudi v zvezi s (teoretiðnim) resevanjem prostorske problematike. Taki sta n.pr. "Geomorfologija na razpotju" (Gams 1962) in "Nekateri aktualni problemi raziskovanja krasa v Sloveniji" (Habix 1974).

$\mathrm{V}$ tem tematskem pregledu nisem posebej opozarjal na dela, ki so neposredno uporabna za resevanje prostorske problematike ali celo dela, ki resitve vsebujejo oziroma so nastala kot rezultat raziskav $\mathrm{v}$ zvezi $\mathrm{s}$ tem. Tudi taka so vmes, najvec $\mathrm{v}$ zvezi $\mathrm{z}$ reševanjem vprasanj v zvezi $z$ vodo: oskrba $z$ vodo, kvaliteta kraskih voda, varovanje vodnih virov, onesnaževanje, problematika odpadnih voda, poplave. Naj naštejem nekaj najznacilnejših naslovov: Javornißki podzemeljski tok in oskrba Postojne $\mathrm{z}$ vodo (Habix 1968), Kraške in hidrološke znacilnosti Košanske doline in njen prispevek k onesnaženosti Notranjske Reke (Habix \& Gospodarið \& Kogovšek 1984), Kvaliteta voda na Notrarjjkem (Kranjc \& Kogovłek 1987) in Poplavni svet ob Notranjski Reki (Kranjc \& Mihevc 1988).

Objavljena dela so predvsem rezultat osnovnih (fundamentalnih) raziskav, ceprav so tudi te lahko aplikativno usmerjene. Vendar so njihovo osnovno znanje in sredstva za raziskave crpana iz osnovno usmer jenih raziskav. Drugace je z neobjavljenimi deli, to je $\mathrm{z}$ rezultati raziskav in nalog, predstavijenimi v obliki elaboratov, porocil, ekspertiz in podobnega, ki jim je skupno to, da so razmnoženi v zelo ome jenem stevilu. $\mathrm{V}$ nadaljnjem besedilu jih bom imenoval kar claboratc. Ti običajno vsebujejo rezultate raziskav, ki so bile finansirane posebej, ne iz fonda za osnovne raziskave, in so zato najpogosteje aplikativne narave. Zato je po eni strani njihova uporabnost vexja - narocnik dobi (vsaj upa tako) neposredni odgovor na zastavljeno vprašanje, brez "balasta", ki ga obiðajno vsebujejo objavljena dela. Po drugi strani pa je v claboratih væasih zbranih veliko podatkov, pomemonih tudi za osnovno poznavanje regije ali problema, a nikakor ne pridejo v šršo javnost. Ne le, da so v arhivih posameznih organizacij in jih ni na javnih seznamih, včasih tudi organizacije - naroðniki ne želijo, da bi podatki prišli v javnost oziroma v splosno rabo, kar je lahko velika škoda.

Prvi inکtitutski elaborati izvirajo iz 1953 in v dobrih 40 letih dela se jih je nabralo 330 . So zelo razliéni, od diplomskih in doktorskih nalog do podatkov analiz in o sestavi muze jsikih razstav. Precej avtorjev je iz vrst drugih strok, ne geografov, vendar so na 
sploకno soavtorji elaboratov stevilnejsi, kot je to pri objavah in je zato obicajno geograf vsaj sodelavec $\mathrm{v}$ raziskovalni skupini, ce že ni nosilec ali avtor elaborata.

Podrobneje predstavljam le elaborate aplikativne narave, $v$ zvezi $z$ reševanjem prostorske problematike. Po tematski razdelitvi gre za elaborate $v$ zvezi $z$ vodo, $z$ gradbenimi deli, $\mathrm{s}$ turistixno izrabo, za elaborate o posebnih speleoloških raziskavah in v zvezi z obrambo.

Preko $30 \%$ poroxil o aplikativnih raziskavah je povezanih $\mathrm{z}$ vodo na krasu, iz cesar je mogoðe razbrati, da je voda na krasu "prostorski faktor" stevilka 1. Gre za raziskave $v$ neposredni zvezi $z$ vodno oskrbo: regionalne študije o vodnih virih, hidrološke in speleoloske raziskave kraß̌ih izvirov in vodnih jam, sledenje podzemeljskih tokov in dolocanje zaledij izvirov. Take studije so lahko skrbno podprte s teoretixnimi izsledki (valorizacija vodnih virov cele regije) ali pa so usmerjene v prakso - crpalni poizkus kraškega izvira. Študije pokrivajo razlið̌no velika ozemlja, od cele regije (vodna oskrba Bele krajine) do obxine, industrijske cone ali enega samega hotela. Najvex raziskav je bilo opravljenih za postojnsko in sosednje obcine, a tudi za oddaljenejše, za Novo Gorico, Belo krajino in ceio Miljevino v BiH.

Drugi elaborati, vezani na raziskavo kraških voda, so predvsem hidrografske študije (sledenje podzemeljskih voda), študije v zvezi s turizmom in melioracijami (poizkusna ojezeritev Cerkniškega polja), $z$ akumulacijami in onesnaževanjem, vkljuřno s preuXevanjem vpliva postojnske cistilne naprave.

Od priprav Studijskih osnov za gradbena dela bi onienil raziskave za avtoceste, ki potekajo oziroma jih gradijo preko krasa. Gre za raziskave kraškega podzemlja in njegovih lastnosti glede na avtoccsto (jame, vrtace, odprte razpoke, grezi, podzemeljski tokovi) in za klimatske znacilnosti s posebnim poudarkom na burji.

Razmeroma pomembne študije so v zvezi s kraškim turizmom, od nataň̌nih meritev in preiskav posameznih jam ali le njihovih delov, od kompletne turistixne ponudbe in izvedbe (Zelške jame) do posameznih detajlov (raziskave za krožno progo v Postojnski jami). Nekaj raziskav je bilo opravljenih tudi v zvezi s pomenom krasa in kraških pojavov v obrambne namene. Ker kaže, da je tudi naša družba vedno bolj ekološko osvešcena, sodelujejo inštitutski geografi v zadnjih letih tudi pri iskanju in določanju primernih mest za smetišca. 
Uspešnost takega geografskega dela je težko oceniti - doloðena dela, ki so potrebovala tudi predhodni elaborat geografske vsebine so bila v celoti izvrక̌na, določeni načrti in elaborati pa so obležali $v$ predalih, ne da bi se zanje se kdo zmenil. Sicer pa avtocesta Vrhnika-Postojna, ki poteka preko globokega krasa, je stara že preko 15 let in se se ni zgodilo, da bi se udrla ali drugače poškodovala zaradi (slabo preuð̌ene) kraške narave ozemlja. Torej tudi praksa potrjuje uspesnost nasih geografov pri reševanju prostorskih vprašanj na krasu. 


\section{LITERATURA}

Gams I., 1962. Geomorfologija na razpot ju. Geografski obzornik, 11, 46-48, Ljubljana.

Gams I., 1962. Morfografski pregled Novomeskih pokrajin. Dolenjska zemlja in ljudje, 31-37, Novo mesto.

Gams I., 1963. KraŠki turizem v polpretekli dobi in sedanja problematika. Turistǐ̌ni vestnik, 11, 298-301, Ljubljana.

Gams I., 1965. Aperçu sur l'hydrologie du karst slovène et sur ses communications souterraines. Naše jame, 7, 51-60, L jubljana.

Habe F., 1967. Problem inventarizacije kraških pojavov na Slovenskem. Naše jame, 9 , 68-72, L jubljana.

Habe F., 1970. Predjamski podzemel jski svet. Acta carsologica, 5, 1-94, Ljubljana.

Habe F., 1973-74. Zašciti podzemeljskega sveta bije plat zvona. Proteus, 36, 361-363, Ljubljana.

Habe F., 1976. Morfološki, hidrografski in speleoloక̌ki razvoj v studenskem fliß̌nem zatoku. Acta carsologica, 7, 1-73, L jubljana.

Habix P., 1968. Javorniški podzemel jski tok in oskrba Postojne $z$ vodo. Naše jame, 10, 47-54, Ljubljana.

Habið P., 1974. Nekateri aktualni problemi raziskovanja krasa v Sloveniji. Zbornik IX.kongresa geografa Jugoslavije, 103-110, Sarajevo.

Habǐ P., 1975. Osnovna speleoioška karta Slovenije, 1.nadaljevanje. Naše jame, 17, 137-150, Ljubljana. Soavtor: R.Gospodarix,I.Kenda,A.Kranjc.

Habi夭 P., 1978. Razporeditev kraških globeli v Dinarskem krasu. Geografski vestnik, 50, 17-31, L jubljana.

Habi夭 P., 1979. Vertikalno prenikanje vode $v$ krasu na primerih Planinske in Postojnske jame. Zbornik referatov 6.HIG, 1, 199-207, Portorož. Soavtor: J.Kogovక̌k.

Habic P., 1984. Kraške in hidrološke značilnosti Košanske doline in njen prispevek k onesnaženosti Notranjske Reke. Acta carsologica, 12, 67-89, Ljubljana. Soavtor: R.GospodariC, J.Kogovšek.

Kranjc A., 1976. Poskus valorizacije kraških votlin v obđini Kođevje z naravovarstvenega vidika. Varstvo narave, 9, 3-20, L jubljana.

Kranjc A., 1987. Kvaliteta voda na Notranjskem. Notranjska, Zbornik 14.zborovanja slovenskih geografov, 167-178, L jubljana. Soavtor: J.Kogovకsk.

Kranjc A., 1987. Postojnska jama (Postojna Cave) - an example of man's impact on the karst underground by tourism. Man's impact in Dinaric Karst (Guide-book), 29-38, Ljubljana. Soavtor: J.Kogovšek.

Kranjc A., 1988. Poplavni svet ob Notranjski Reki. Geografski zbornik, 28, 195-218, Ljubljana. Soavtor: A. Mihevc.

Savnik R., 1959. Izviri Vipave. Naše jame, 1, 30-32, Ljubljana.

Šerko A., 1949. Kotlina Škocjan pri Rakeku. Geografski vestnik, 20-21(1948-49), 195-202, L jubljana. 


\section{THE CONTRIBUTION OF THE GEOGRAPHERS FROM THE INSTITUTE FOR KARST RESEARCH TO THE SOLUTION OF SPACE PROBLEMATICS}

The idea to promote Postojna as international karstological and speleological center involving economical, cultural-pedagogical and scientific activities dates from the begining of the century. For this pourpose in 1929 the Italian Speleological Institute was founded. In 1947 the Slovene Academy of Sciences and Arts founded the Speleological Institute, renamed in 1954 to the Institute for Karst Rcsearch, which is organized from 1984 within the Scientific Research Center of the Academy. The Institute started with work in 1950, when the acting manager, geographer R.Savnik got the collaborators. At the beginning the program was strictly speleological, but new researchers brought new viewpoints and thus the research activity widened and was oriented to karstological researches too. About $70 \%$ of the research capacities are dedicated to fundamental researches with common title Basic Karst Research, the remaining $30 \%$ are left for applied tasks.

Among the managing workers of the Institute there was usually at least one geographer, the members of the Scientific Council are geographers too. In past 9 geographers have worked on the Institute, and now there are 4 geographers among 13 rcsearchers.

As the fundamental researches are essential on the Institute the share of applicative ones is relativcly small. All the researches are connected to karst. The geographers within the Institute have published about 800 works. Among them 205 are treating the space problematics, and 186 are such where the results of regional investigations are presented. Other works deal with geomorphology, hydrography, speleology, climate, karst processes and problematics of spatial data collection and display.

The works treating the hydrographic questions predominate, they either give the revicw of whole or they are very specialised. The contributions with speleological content follow. Almost the same number comprehend geomorphological contributions. Here too the span is rather wide, from the whole areas to particular details. Two contributions treat the climate and four karst processes. Six contributions deal with the question of informatics, about the data on karst caves mostly. The contributions about the nature protection are scarce, either they are rather general appeals or concrete regarding the space. There are 12 contributions about the tourism in cavcs and on karst. Fartly they are principled, theoretical contributions respectively, partly they treat the concrete examples.

Among the published works there are some in direct contact with space problematics, mostly connected to solution of water supply, karst water quality, karst water sources protection, pollution, waste waters problematics and floods. 
The first studies made on the Institute date from 1953 and in good 40 years about 330 of them were achieved. They are very different, from master and PhD Thesis to data about the analyses and structure of museum exhibitions. A lot of authors belong to other professions, but one geographer is at least either a collaborator or the study's author.

Only 80 studies of applicative nature connected to solution of space problematics exist. More than $30 \%$ of the reports of applicative researches are in direct contact with water supply: regional studies on water sources, hydrological and speleological investigations of karst springs and water caves, underground water tracing and definition of springs catchment areas. Other studies, connected to karst water problematics are mostly hydrographical researches, connected to tourism and meliorations, accumulations and pollution.

Within the same frame the studies for building works for motorway construction across the karst have to be mentioned. These are researches of the karst underground and its properties (caves, dolines, open fissures, sinkholes, underground flows) and its climatic characteristics with special stress on wind bora.

Important studies are connected to karst tourism, from precise surveys and explorations of particular cave to complete touristic offer and display. Some researches were done regarding the importance of karst and karst phenomena for defense purposes and in last years in connection with dumping-ground.

It is cifficult to evaluate the efficiency of such geographical work. Just for illustration I would like to mention that the motorway Vrhnika - Pcstojna, going through the karst and being old for more than 15 years, did not yet collapse and is not damaged in other way because of (badly studied) karst nature of the area. Thus the practice confirms the efficiency of institute geographers by solving the space questions on karst. 